Uniwersytet im. Adama Mickiewicza, Poznań

\title{
Ewolucja stosunków pomiędzy Ukrainą i UE
}

W czasie kolejnego szczytu Ukraina-Unia Europejska, który odbył się w Kijowie w grudniu ubiegłego roku, nie była podpisana umowa stowarzyszeniowa. Wprawdzie Ukraińcy mieli nadzieję, że dojdzie do tego, ale Europejczycy nie byli do tego skłonni. Korupcja, zbyt powolne tempo wprowadzania reform, rosnące zadłużenie, ciąłe kryzysy polityczne - zarzuty stawiane Ukrainie są liczne i poważne, i ciagle jedne i te same.

Minęło prawie 20 lat od czasu proklamowania przez Ukrainę niepodległości i ogłoszenia europejskiego kierunku rozwoju. Co zmieniło się przez te lata, na jakim poziomie znajduje się współpraca, jakie są szanse Ukrainy na przystapienie do UE? Na te pytania spróbujemy znaleźć odpowiedź.

Globalna transformacja porządku międzynarodowego na początku lat dziewięćdziesiątych XX wieku stworzyła warunki dla realizacji aspiracji narodu ukraińskiego do niepodległości. Rezultatem tego była Ustawa o niepodległości Ukrainy z 24 sierpnia 1991 r. i wyniki referendum z 1 grudnia tego roku.

Podobnie jak wszystkie poradzieckie kraje, Ukraina była zmuszona przejść przez duże przemiany gospodarcze. Jednak w porównaniu z większością krajów w Europie Wschodniej, Ukraina zetknęła się z trudnościami w budowaniu nowego niezależnego państwa. Niestety, Ukraina nie posiadała własnej polityki zagranicznej ze względu na brak trwałej państwowości (przez ponad 300 lat wchodziła w skład Imperium Rosyjskiego, potem 70 lat - ZSRR). W ramach Związku Radzieckiego gospodarka Ukrainy stanowiła nieodłączną część wspólnej gospodarki radzieckiej i była podporządkowana wspólnemu planowi dla wszystkich republik. Według ocen ekonomistów, 70-80\% przedsiębiorstw przemysłowych działających na Ukrainie wytwarzało surowce i części składowe, co oznacza, że jedynie $20 \%$ produkowało wyroby końcowe. System komunistyczny funkcjonował 70 lat i miał wielki wpływ nie tylko w sferze gospodarczej, ale i w społecznej, i świadomościowej.

Ukraina od samego początku swojej niezależności deklarowała zbliżenie z Unią Europejską. Oficjalne stosunki pomiędzy Ukrainą a UE zostały 
nawiązane 2 grudnia 1991 r., kiedy minister spraw zagranicznych Holandii, przewodniczącej wówczas w Unii, oficjalnie uznał niepodległość Ukrainy. Do pierwszego spotkania przywódców - prezydenta Leonida Krawczuka z Jacquesem Delorsem - przewodniczącym Komisji Europejskiej, doszło 14 września 1992 r., a w październiku 1993 r. otwarto przedstawicielstwo UE w Kijowie. Ukraina przedstawiona w Brukseli z 1992 r., ale przedstawicielstwo otwarto dopiero w 1996 r.

Zwykle naukowcy rozdzielają stosunki Unii Europejskiej i Ukrainy na dwa okresy: do pomarańczowej rewolucji i po niej. Alicja Stępień-Kuczyńska $^{1}$ w stosunkach pomiędzy Ukrainą a UE wydziela trzy okresy. Pierwszy z tych okresów, „obojętny”, obejmował okres 1991-1994; drugi i trzeci - „partnerstwa” i „rozczarowania”, obejmowały lata 1995-1999 oraz 1999-2004 (pierwsza i druga kadencji prezydenta Leonida Kuczmy). Można dodać czwarty etap - czas po pomarańczowej rewolucji, rozdzielony na dwie części - „zachwytu” i „rozczarowania i zmęczenia”. Po wyborach prezydenta Ukrainy być może nastapi nowy etap, który przyniesie zmiany w kierunku partnerstwa i pogłębienia współpracy.

Według niektórych politologów, rozbrojenie Ukrainy aktywizowało stosunki Ukrainy z Unia, które zaczęły się aczkolwiek po 1994 roku. W sferze polityki bezpieczeństwa Ukraina dokonywała wielokrotnych korekt. Na początku lat 90. na ukraińskim terytorium znajdowało się dużo broni jądrowej: 130 napędzanych ciekłym paliwem rakiet SS-19 z sześcioma głowicami bojowymi - każda po 0,55 megaton, 46 rakiet SS-24 z dziesięcioma głowicami bojowymi po 0,44 megaton oraz 44 bombowce strategiczne (dla porównania: bomby zrzucone w 1945 r. na Hiroszimę i Nagasaki miały moc „tylko” 0,02 megaton) ${ }^{2}$. Taki spadek plasował Ukrainę na trzecim miejscu po USA i Rosji. W listopadzie 1994 r. Ukraińska Rada Najwyższa przyjęła Ustawę o przystąpieniu Ukrainy do międzynarodowego Traktatu o nierozprzestrzenianiu broni jądrowej jako państwa nieposiadającego broni jądrowej, a w maju 1996 r. ostatnia głowica była wywieziona do Rosji. Rezygnacja z broni jądrowej umocniła pozycję Ukrainy na arenie międzynarodowej i stworzyła dogodny klimat do współpracy.

1 A. Stępień-Kuczyńska, M. Słowikowski, Unia Europejska a państwa Europy Wschodniej, Warszawa 2008, s. 101.

2 M. Riabczuk, Atomowa tęsknota: Ukraina a broń jądrowa, „Polski przegląd dyplomatyczny" 2009, nr 4-5, s. 30-31. 
W 1989 r. między Ukrainą a ZSRR została podpisana umowa o współpracy gospodarczej i handlu na 10 lat. Jej celem było stworzenie korzystnych warunków dla harmonijnego rozwoju stosunków handlowych, a mianowicie, taryf celnych i stopniowe usuwanie ograniczeń ilościowych w handlu produktami przemysłowymi, prócz produktów tekstylnych, produktów stalowych i produktów morskich.

Wspólnota Niepodległych Państw (WNP), w tym i Ukraina, odziedziczyły wszystkie międzynarodowe umowy i zobowiązania z byłego Związku Radzieckiego, zgodnie z tzw. układem białowieskim, rozwiązującym ZSRR i powołującym do życia nową organizację integracyjną. W związku z tym porozumienie w 1989 r. założyło pierwsze ramy umowne.

Po rozpadzie Związku Radzieckiego w grudniu 1991 r. i po uznaniu niepodległości byłych republik przez Europejską Wspólnotą Gospodarczą (EWG), rozpoczęły się negocjacje w sprawie nowych umów między UE i nowymi niepodległymi krajami Europy Wschodniej i Azji Centralnej. Wybrano formułę Umów o Partnerstwie i Współpracy - UPiW (Partnership Cooperation Agreement - PCA). Koncepcja nowych umów powstała pod koniec 1992 r. w Brukseli. Porozumienia takie podpisano ze wszystkimi krajami regionu. Układy z Turkmenistanem i Białorusią nie weszły w życie z powodu sytuacji politycznej w tych państwach.

Negocjacje z Ukrainą toczyły się od marca do listopada 1993 r., umowę podpisano 14 czerwca 1994 r. w Luksemburgu. Ukraina podpisała ten układ jako pierwsza z byłych republik ZSRR (prócz republik bałtyckich, które miały inne umowy), jeszcze przed Rosją. Po podpisaniu PCA Rada Najwyższa Ukrainy szybko ratyfikowała ten dokument - już 10 listopada, natomiast ratyfikacja w krajach UE była dłuższa. Chcąc umożliwić rozwój kontaktów handlowych 1 czerwca 1995 r. podpisano tzw. układ tymczasowy (Interim Agreement on trade and trade-related matters between the European Community, the European Coal and Steel Community and the European Atomic Energy Community and Ukraine), wprowadzający większość klauzul gospodarczych PCA, który wszedł w życie 1 lutego 1996 r.

PCA wszedł w życie z dniem 1 marca 1998 r. i została zawarta na następny okres 10 lat, po którym to czasie mogła ona zostać przedłużona na podstawie obustronnego porozumienia. Układ tworzył podstawy prawne, polityczne, gospodarcze i ramowe relacji między Unią Europejską a Ukrainą. W PCA wyznaczono priorytety współpracy między Ukrainą a UE: energetyka, handel i inwestycje, prawo i sprawy wewnętrzne, zbliżenie ustawodawstwa Ukrainy do ustawodawstwa UE, ochrona środowiska, 
transport, współpraca transgraniczna, współpraca naukowa, techniczna i badań kosmicznych. Jednym z najważniejszych zadań formułowanych w ramach PCA jest wspieranie wysiłków podejmowanych przez samą Ukrainę na rzecz budowy demokracji i wolnego rynku. Utworzono złożoną, wielopoziomową strukturę wspólnych instytucji, co ułatwia realizację sformułowanych celów. Główne struktury współpracy, przewidziane w PCA, obejmują: doroczne szczyty, doroczną Radę Współpracy na szczeblu ministerialnym, komitety i podkomitety współpracy, szczyty Ukraina-UE z udziałem prezydenta (dwa razy w roku), Komitet ds. współpracy z udziałem premiera, Radę ds. współpracy na poziomie ministerialnym, Komitet współpracy parlamentarnej, stałe konsultacje Ukraina-Trójka UE. Według Ministerstwa Spraw Zagranicznych Ukrainy rocznie odbywa się ponad 80 oficjalnych spotkań i konsultacji na różnych szczeblach. W ramach Komitetu funkcjonują podkomitety (tematyczne): ds. handlu i inwestycji; ds. finansów, gospodarki i statystyki; ds. transportu i energetyki, ochrony środowiska, szkoleń i technologii; ds. celnych, współpracy transgranicznej, walki z nielegalną migracją, praniem brudnych pieniędzy i narkotykami.

PCA był oceniany niejednoznacznie. Według Alana Mayhewa ${ }^{3}$ w PCA podkreślało się znaczenie współpracy, ale daleko odbiegało się od agendy reform w ramach układu o stowarzyszeniu zawartych z przyszłymi nowymi państwami członkowskimi w Europie Środkowej. A. Szeptycki stwierdził, że Układy o Partnerstwie i Współpracy dla państw obszaru WNP „Z jednej strony stworzyły podstawę pod dialog polityczny UE z nowymi państwami niepodległymi i uniemożliwiły rozwój współpracy handlowo-gospodarczej. Z drugiej zaś wiele zapisów UPW pozostało niezrealizowanych: dotyczy to m.in. stworzenia strefy wolnego handlu z udziałem państw Europy Wschodniej. Na negatywną ocenę zasługuje również fakt, że podpisując Układy o Partnerstwie i Współpracy, Unia Europejska w uprzywilejowany sposób potraktowała Rosję, pokazując w ten sposób nowym państwom niepodległym, jakie są jej priorytety w sferze polityki wschodniej”"4. Układ był znaczącym dla Ukrainy, zaś stworzył szerokie podstawy dla rozwoju stosunków Ukrainy i UE.

3 A. Mayhew, Ukraine and the European Union: financing accelerating integration, November 2008, s. 84.

4 A. Szeptycki, S. Kardaś, Polityka UE wobec Europy Wschodniej, Kaukazu Południowego i Azji Środkowej, w: Dyplomacja czy siła? Unia Europejska w stosunkach międzynarodowych, pod red. S. Parzymiesa, Warszawa 2009, s. 243. 
Drugim krokiem kształtowania relacji z Ukrainą było przyjęcie pierwszego Planu Działań w grudniu 1996 r. Obejmował on okres do 2002 r. Głównymi priorytetami było wzmocnienie dialogu politycznego, wspieranie reform demokratycznych i gospodarczych, reforma sektora energetycznego (linia przesyłu ropy i gazu przez Ukrainę do krajów europejskich), współpraca regionalna i transgraniczna. We wrześniu 1997 r. w Kijowie odbył się pierwszy szczyt Ukraina-UE, na którym potwierdzono proeuropejski wybór Ukrainy. Najowocniejszym rokiem współpracy między Ukrainą a UE był 1998 r.: pierwsze spotkanie Rady ds. Współpracy między Ukrainą a Wspólnotami Europejskimi (na którym Ukraina oficjalnie ogłosiła zamiar o uzyskaniu statusu państwa stowarzyszonego z UE), wejście w życie PCA, podpisanie przez Prezydenta Ukrainy Dekretu o Zatwierdzeniu Strategii Integracji Ukrainy z UE, Dekret Gabinetu Ministrów Ukrainy o Wprowadzeniu mechanizmu przystosowania prawa Ukrainy do Unii Europejskiej, utworzono Centrum tłumaczeń prawa Europejskiego, drugi szczyt Ukraina-UE w Wiedniu, pierwsze posiedzenie Komitetu ds. Współpracy Ukraina-UE, na którym przyjęto decyzję o opracowaniu strategii UE w sprawie Ukrainy. W następnym roku UE wysoko oceniła poziom rozwoju stosunków z Ukrainą.

W 1999 r. UE przyjęła wobec Ukrainy wspólną strategię (European Council Common Strategy on Ukraine). Na obszarze poradzieckim wspólną strategię wypracowano w tym okresie jeszcze tylko wobec Rosji. Wspólna strategia UE została przyjęta na cztery lata z możliwością przedłużenia. W Strategii określone zostały cele UE wobec Ukrainy oraz instrumenty i środki ich realizacji.

Według Wspólnej Strategii UE wobec Ukrainy, Unia Europejska posiadała w odniesieniu do Ukrainy następujące cele strategiczne:

- przyczynianie się do powstania stabilnej, otwartej i pluralistycznej demokracji na Ukrainie, regulowanej przez państwo prawa i wspierającej stabilnie funkcjonującą gospodarkę rynkową, co przyniesie korzyści całej ludności Ukrainy;

- współpraca z Ukrainą w dziedzinie utrzymania stabilności i bezpieczeństwa w Europie i na świecie oraz na wynajdowaniu skutecznych reakcji na wspólne wyzwania, jakie stoją przed kontynentem;

- zwiększenie ekonomicznej, politycznej i kulturalnej współpracy z Ukrainą, jak również współpracy w dziedzinie wymiaru sprawiedliwości i spraw wewnętrznych.

Stwierdzono, że Unia Europejska „uznaje europejskie aspiracje Ukrainy i proeuropejski wybór Ukrainy. UE pozostaje mocno zaangażowana 
we współdziałanie z Ukrainą na poziomie państwowym, regionalnym i lokalnym, mającym na celu wspieranie pomyślnych przemian politycznych oraz ekonomicznych na Ukrainie, które ułatwią Ukrainie dalsze zbliżenie do UE. UE i jej Państwa Członkowskie pragną podzielić się z Ukrainą swoim zróżnicowanym doświadczeniem w budowaniu nowoczesnych struktur politycznych, ekonomicznych, społecznych i administracyjnych, w pełni uznając, że główna odpowiedzialność za przyszłość Ukrainy spoczywa na niej samej”, . Unia podkreśliła, że udzieli pomocy Ukrainie, ale Ukraina powinna sama budować swoją przyszłość i wybierać swoją drogę rozwoju.

Po rozpadzie Związku Radzieckiego Unia Europejska przygotowała dla krajów nowoutworzonej Wspólnoty Niepodległych Państw (WNP) program pomocy technicznej zwany TACIS (Technical Assistance for the Commenwealth of Independent States - TACIS). Początkowo był on skierowany jeszcze do ZSRR (powstał w 1990 r.). Głównym celem programu TACIS jest wspieranie przejścia do gospodarki rynkowej i wzmocnienie demokracji i państwa prawa w krajach będących beneficjentami. Działania te powinny były przyczynić się do stworzenia warunków do wzrostu gospodarczego w krajach WNP oraz wypracowania rzeczywistego partnerstwa z UE. Stosunki między Unią Europejską i państwami będącymi beneficjentami TACIS opierały się na porozumieniach o partnerstwie i współpracy (PCA). Według porozumienia planowanie działań TACIS opierało się na dialogu, co oznacza, że Komisja i państwa będące beneficjentami powinny wspólnie uzgadniać priorytety i projekty na wszystkich poziomach programowania i etapach identyfikacji projektów.

Ukraina stała się, w kolejności ważności, drugim beneficjentem programu po Rosji. W latach 1991-2006 Unia przeznaczyła 7 mld euro na program TACIS, z czego Ukraina otrzymała prawie 2,5 mld euro (35\% całości środków przewidzianych w programie, w porównaniu Rosja otrzymała $40 \%)^{6}$. Program miał duże znaczenie dla Ukrainy. Pomoc przeznaczono na bezpieczeństwo nuklearne, reformę administracji, reformy instytucjonalne i prawne, rozwój infrastruktury energetycznej, transportowej i telekomunikacyjnej, doradztwo polityczne oraz rozwój gospodarki

5 Wspólna strategia Rady Europejskiej z dnia 11 grudnia 1999 r. w sprawie Ukrainy, wpia.uni.lodz.pl/zeupi/pliki_upload/Wspólna\%20strategia\%20Rosja.doc, 1.02.2010.

6 The EU's Relationship with the Countries of Eastern Europe \& Central Asia, http://ec.europa.eu/europeaid/where/neighbourhood/country-cooperation/ukraine/ukraine_en.htm. 
rolnej, współpracę transgraniczną (rozbudowa przejść granicznych Ukraina-UE, w tym z Polską i Słowacją). Ze środków TACIS finansowana była budowa kompleksu do obsługi stałych odpadów radioaktywnych (PKPTRV). Koszt projektu wyniósł $47 \mathrm{mln}$ euro, zatem wkład WE - 43,578 milionów euro, a Ukrainy - 3,422 milionów euro.

W latach 2000-2003 Werchowna Rada Ukrainy uchwaliła szereg ustaw dostosowujących prawodawstwo ukraińskie do standardów europejskich. Była ratyfikowana Konwencja o Ochronie Praw Człowieka i Swobód Obywatelskich oraz Protokół nr 6, który ustanawia zniesienie kary śmierci; wprowadzono nowy Kodeks Kryminalny Ukrainy i Kodeks Cywilny Ukrainy ${ }^{7}$. W 2002 roku Ukraina dołączyła się do Konwencji o Statusie Uchodźców i Protokołu o Statusie Uchodźców, a tym samym prawo ukraińskie zostało całkowicie dostosowane do europejskich i międzynarodowych norm w dziedzinie ochrony praw tych kategorii osób. Także była wprowadzona Mniejsza Reforma Prawna w sądownictwie.

Piąte rozszerzenie Unii Europejskiej w 2004 r. o kraje Europy Środkowo-Wschodniej, znacznie zbliżyło UE do krajów Europy Wschodniej. Ukraina była zaniepokojona potencjalnym wpływem politycznym i gospodarczym tego rozszerzenia. Od lat 90. ruch bezwizowy z Europą Środkowo-Wschodnią stał się normą, a handel transgraniczny stał się znaczący dla gospodarki kraju. Rozszerzenie UE o kraje Europy Środkowo-Wschodniej oznaczało ustanowienie zewnętrznej granicy UE pomiędzy nowymi państwami członkowskimi a Europą Wschodnią oraz koniec podróżowania bez wiz.

Debata nad stworzeniem konkretnej wizji polityki sąsiedztwa nabrała w Unii Europejskiej tempa od 2002 r. Pierwsza propozycja, zgłoszona przez Wielką Brytanię i Danię, zakładała objęcie statusem ,specjalnych sąsiadów" państw położonych na wschód od rozszerzonej UE (to jest Ukrainy, Białorusi oraz Mołdawii, New Neighbours Initiative z kwietnia 2002 r.). Szybko jednak, na skutek presji m.in. Francji i Hiszpanii, zaniepokojonych rysującą się według nich groźbą marginalizacji państw południowego basenu Morza Śródziemnego, do planów unijnej polityki sąsiedztwa włączono także i te pozaeuropejskie kraje. Później dołączyły się jeszcze trzy państwa Południowego Kaukazu, które graniczą z Turcją: Armenia, Gruzja i Azerbejdżan.

7 Szerzej: ustawodawstwo Ukrainy, www.zakon.rada.gov.ua. 
Komisja Europejska przedstawiła nową politykę sąsiedztwa zwaną europejską polityką sąsiedztwa - EPS (European Neighbourhood Policy) w maju 2004 r. Celem polityki jest wzmocnienie związków z sąsiednimi krajami partnerskimi poprzez szereg nowych form współpracy i pomocy.

Warto zaznaczyć, że od uczestnictwa w europejskiej polityce sąsiedztwa bardzo stanowczo odżegnała się Federacja Rosyjska, na szczycie w Sankt Petersburgu w maju 2003 r. zadecydowano, że stosunki UE-Rosja przyjmą postać „strategicznego partnerstwa”.

W ostatecznym rezultacie, EPS objęła specyficzną grupę krajów, które spełniały łącznie trzy warunki: leżały w geograficznym sąsiedztwie UE, posiadały z Unią ustalone relacje traktatowe (tzn. PCA lub umowę stowarzyszeniowa) oraz nie miały uprzednio zarysowanej perspektywy członkostwa. Dzisiaj obejmuje ona 16 państw z Europy Wschodniej, Afryki Północnej i Południowego Kaukazu.

Głównym narzędziem EPS jest Plan Działań (PD), dokument uzgadniany w toku dwustronnych negocjacji przez UE i dane państwo. PD jest dokumentem politycznym, zawieranym na okres od trzech do pięciu lat, składającym się ze zbioru priorytetów, które mają zostać osiągnięte w czasie, na jaki został zawarty. W zamian Unia oferuje pomoc finansową i techniczną oraz pogłębioną integrację gospodarczą. Unia pomaga we wdrażaniu PD za pomocą istniejących programów finansowych (od 1 stycznia 2007 r. program TACIS zastąpił nowy, stworzony z myślą o polityce sąsiedztwa zintegrowany instrument finansowy ENPI - European Neighbourhood Policy Instrument) oraz od niedawna także za pośrednictwem mechanizmów wsparcia administracji w ramach programów twinningowych.

W styczniu 2005 r. Komisja Europejska zaoferowała Kijowowi dziesięciopunktowe uzupełnienie Planu Działań. W aneksie tym zapowiedziano, że nowe porozumienie unijno-ukraińskie, które ma zastapić układ o partnerstwie i współpracy, będzie miało pogłębiony charakter oraz skupiono się na szeregu bardziej szczegółowych kwestii bodźców ekonomicznych, których zastosowanie częściowo zostało uzależnione od reform wprowadzanych przez nową ekipę nowego Prezydenta Ukrainy W. Juszczenki. Punkty te dotyczyły m.in. ${ }^{8}$ :

- pogłębienie związków handlowych i gospodarczych między UE i Ukrainą (negocjacje w sprawie umowy o handlu produktami stalowymi na

8 EU/Ukraine action plan, treść dokumentu dostępna: http://ec.europa.eu/world/ enp/pdf/action_plans/ukraine_enp_ap_final_en.pdf. 
rok 2005 i sfinalizowanie umowy o handlu produktami tekstylnymi na rok 2005);

- poparcie przez UE starań Ukrainy dotyczących wejścia do Światowej Organizacji Handlu, co prowadziłoby następnie do zawarcia umowy o wolnym handlu z UE;

- uznanie Ukrainy za funkcjonująca gospodarkę rynkową;

- rozpoczęcie prawdziwych negocjacji dotyczących ułatwień wizowych, negocjacje w sprawie umowy UE-Ukraina o readmisji;

- współpraca w kilkunastu kluczowych sektorach, włączając energię, transport i środowisko;

- zwiększenie poparcia dla procesu przybliżania prawa ukraińskiego i unijnego (dostosowanie do unijnych standardów sanitarnych i fitosanitarnych);

- zwiększenie dostępu Ukrainy do finansów Europejskiego Banku Inwestycyjnego.

Plan Działania z Ukrainą podpisany został 21 lutego 2005 r. i był przyjęty na trzy lata.

Ukraina z rozczarowaniem przyjęła propozycję Komisji Europejskiej dotyczącą EPS z kilku względów. Po pierwsze, EPS pozostaje jednostronną inicjatywą UE wobec krajów, objętych tą polityką. Ukraina potwierdza namiar rozwijania stosunków dwustronnych w kierunku celu strategicznego - przystąpienia do UE. Po drugie, kluczowe zasady EPS są dalekie od narodowych interesów Ukrainy. W szczególności dotyczy to takich elementów EPS jak:

- pozycjonowanie polityki sąsiedztwa jako alternatywa jej rozszerzenia;

- braku rozróżnienia pomiędzy partnerami z Europy i spoza niej, w tym w odniesieniu do ostatecznych celów i perspektyw stosunków z UE;

- EPS nie przewiduje możliwości wprowadzenia wzajemnego bezwizowego reżimu pomiędzy UE a krajem-partnerem.

Plan działań był korzystny dla Ukrainy. 1 grudnia 2005 r. podczas szczytu UE-Ukraina, Unia przyznała Ukrainie status kraju z gospodarką rynkowa; podpisano wtedy istotne Memorandum w sprawie współpracy energetycznej oraz umowę o współpracy w ramach systemu Galileo.

Według Marcina Kaczmarskiego ${ }^{9}$ w wymiarze bilateralnym (UE - partner na wschodzie z EPS) nowe podejście do wschodnich sąsiadów

9 M. Kaczmarski, Polska polityka wschodnia na tle polityki wschodniej Unii Europejskiej czyli Europa idzie na Wschód (po 2005 roku), treść artykułu dostępna: 
najbardziej widoczne było w przypadku Ukrainy. Ukraina jest określana przez UE jako kraj, w odniesieniu do którego Unia jest gotowa wyjść poza współpracę, w stronę stopniowej integracji ekonomicznej i pogłębienia współpracy politycznej. Przy określaniu formuły relacji z Ukrainą używa się pojęcia „uprzywilejowane stosunki”.

18 czerwca 2007 r. przyjęto zrewidowany Plan Działania z Ukrainą w sferze Wolności, Bezpieczeństwa i Sprawiedliwości. 5 marca 2007 r. rozpoczęły się negocjacje odnośnie nowego PCA między UE i Ukrainą. Jest ono określane jako „Wzmocnione porozumienie” (enhanced agreement). Jako że Ukraina jest już członkiem Światowej Organizacji Handlu (WTO), rozpoczęto również negocjacje o głębokiej strefie wolnego handlu. W 2007 r. UE rozpoczęła negocjacje z Ukrainą dotyczące protokołu o udziale Ukrainy w programach i agendach Wspólnoty. W 2007 r. pierwsze alokacje finansowe w ramach Governance Facility trafiły do Ukrainy.

W początkach 2008 r. skończył swoje funkcjonowanie Plan Działania dla Ukrainy i przyjęto przedłużenie jego funkcjonowania o rok, bez zasadniczej zmiany treści.

Obecnie kluczową sprawą jest kształt nowego porozumienia PCA. Jego częścią ma być porozumienie o głębokiej strefie wolnego handlu, która objęłaby nie tylko liberalizację handlu towarami, ale również usługami. UE jest zainteresowana zbliżeniem prawodawstwa ukraińskiego do unijnego, wewnętrzną stabilizacją Ukrainy oraz ścisłą współpracą gospodarczą. Politycznie UE poza „uprzywilejowanymi stosunkami” nie wydaje się być gotowa do większej otwartości na Ukrainę.

Polska i Szwecja zaproponowały wspólną inicjatywą pod nazwą Wschodnie Partnerstwo UE na posiedzeniu ministrów spraw zagranicznych ,27” w Brukseli w maju 2008 r. Celem projektu ma być wzmacnianie regionalnej współpracy ze wschodnimi sąsiadami Unii: Ukrainą, Mołdawią, Gruzją, Azerbejdżanem, Armenią oraz na poziomie technicznym i eksperckim z Białorusią. Rosja na zasadzie dobrowolności może uczestniczyć w niektórych projektach. Partnerstwo Wschodnie jest częścią Europejskiej Polityki sąsiedztwa. W maju 2009 r. zostało powołane Partnerstwo Wschodnie na szczycie w Pradze.

Do głównych celów Partnerstwa Wschodniego należą:

- doprowadzenie do ustanowienia politycznego stowarzyszenia,

- stworzenie stref wolnego handlu państw partnerskich z UE, 
- postępująca liberalizacja reżimu wizowego,

- unifikacja prawna,

- wzmocnienie współpracy w zakresie bezpieczeństwa energetycznego,

- wsparcie dla małych i średnich przedsiębiorstw.

Wschodnie partnerstwo skierowane jest na rozwój stosunków dwustronnych między państwami partnerskimi z UE. Partnerstwo Wschodnie to plan rozwoju relacji między Unią a państwami Europy Wschodniej i Kaukazu Południowego, który umożliwia im stopniowe włączanie się do polityk i programów unijnych oraz integrację ze wspólnym rynkiem. W wymiarze dwustronnym zakłada podpisanie umów stowarzyszeniowych oraz utworzenie szeroko zakrojonych i kompleksowych stref wolnego handlu. PW umożliwia także wielostronną współpracę wschodnich sąsiadów UE objętych EPS. Obejmuje ona m.in. regularne spotkania na szczeblu szefów państw i rządów, ministrów spraw zagranicznych, wysokich urzędników oraz ekspertów. Ma to być forum wymiany informacji i doświadczeń krajów partnerskich, pełniące funkcję mechanizmu budowy zaufania.

Na realizację Partnerstwa Wschodniego Komisja Europejska zaproponowała przeznaczyć $600 \mathrm{mln}$ euro ponad środki już przewidziane w budżecie 2007-2013 na bilateralną współpracę UE z jej sąsiadami w ramach Europejskiej Polityki Sąsiedzkiej (EPS) - 12 mld euro na całą EPS na lata 2007-2013, w tym np. na Ukrainę $494 \mathrm{mln}$ euro do 2010 roku. Jak podkreśliła Ferrero-Waldner, z tych dodatkowych $600 \mathrm{mln}$ euro tylko $350 \mathrm{mln}$ to nowe środki z tzw. marginesu z rubryki na politykę sąsiedzką i stosunki zewnętrzne. $250 \mathrm{mln}$ euro KE chce wyasygnować ze środków na regionalne programy w ramach EPS na Wschodzie ${ }^{10}$.

Zwykle Unia Europejska zawiera umowy o Stowarzyszeniu z państwami nieczłonkowskimi. Taka umowa przewiduje przyjęcie zobowiązań przez państwo partnerskie do realizacji reform politycznych, gospodarczych, handlowych albo reform w dziedzinie praw człowieka. Ze swojej strony UE zobowiązuje się pozwolić tym krajom korzystać z preferencyjnego dostępu do niektórych lub wszystkich rynków UE, jak również udzielać pomocy finansowej i technicznej.

Umowa o stowarzyszeniu będzie określać nie tylko prawne stosunki Ukrainy i Unii Europejskiej, lecz także pobudzać Ukrainę do społecznych i gospodarczych reform. Dokument przewiduje współpracę stron w roz-

10 Partnerstwo Wschodnie - raport otwarcia, pod red. B. Wojny, M. Gniazdowskiego, Warszawa, maj 2009, s. 7. 
maitych kierunkach, głównie w zakresie gospodarczym. Główny składnik tej umowy jest stworzenie strefy wolnego handlu.

$\mathrm{W}$ dniu prezentacji PW na spotkaniu ministrów spraw zagranicznych krajów UE ukraińskie MSZ w oficjalnym komentarzu przywitało z zadowoleniem tą inicjatywę, stwierdzając jednak, że proponowany program świadczy o konieczności wypracowania przez UE efektywnego wschodniego wymiaru i powinien przewidywać nadanie jasnej perspektywy członkostwa w UE jej „europejskim sąsiadom”. Miesiąc później, po zaaprobowaniu PW przez Radę Europejską, MSZ Ukrainy w kolejnym komentarzu zaznaczało, że realizacja PW powinna odzwierciedlać specyfikę każdego kraju-partnera oraz uwzględniać stan jego demokracji, gospodarki i deklarowany końcowy cel stosunków z UE. Wyrażono zarazem nadzieję, że program nie będzie miał na celu wykluczenia w elegancki sposób perspektywy członkostwa Ukrainy w UE ${ }^{11}$.

Podczas spotkania Prezydenta Ukrainy z przewodniczącym Parlamentu Europejskiego Hansem Gertem Poetteringiem w Kijowie, Ukrainie zaproponowano główną rolę Wschodniego Partnerstwa UE. Przewodniczący zaproponował opracować wspólną strategię bezpieczeństwa energetycznego, jednocześnie Ukraina ma utrzymywać dobre stosunki z Moskwą. Partnerstwo Wschodnie zostało na Ukrainie przyjęte pozytywnie.

Ukraina jest dla UE strategicznie istotnym państwem z punktu widzenia jej bezpieczeństwa energetycznego. Przystapienie Ukrainy do Traktatu o Wspólnocie Energetycznej i zakończenie synchronizacji zjednoczonego systemu energetycznego Ukrainy z ENTSOE (europejską siecią operatorów systemów przesyłowych energii elektrycznej) będzie stanowić kolejny wkład we wspólne europejskie bezpieczeństwo energetyczne i z zadowoleniem przyjmuje postęp we wspólnym zwiększaniu bezpieczeństwa elektrowni jądrowych. M.in. w 2007 r. UE udzieliła prawie $87 \mathrm{mln}$ euro na poparcie ukraińskiego sektora energetycznego ${ }^{12}$.

Debata w Unii Europejskiej na temat bezpieczeństwa energetycznego toczy się z narastającą intensywnością, do czego przyczynił się bez wątpienia kryzys gazowy rosyjsko-ukraiński ze stycznia 2009 r. Pierwszym zdecydowanym krokiem Unii stało się dopiero podpisanie (23 marca 2009 r.) z Ukrainą deklaracji o gotowości do współpracy i finansowaniu modernizacji ukraińskiego systemu gazociagów.

11 Ibidem, s. 65.

12 Treść dokumentu dostępna: http://ua-energy.org/uploads/files/pdf/external_energy_policy_en.pdf. 
W marcu 2009 r. odbyła się w Brukseli konferencja „EU-Ukraine: Partners for securing gas to Europe" dotycząca modernizacji ukraińskiego systemu transportującego gaz. Komisarz ds. stosunków wewnętrznych, Benita Ferrero-Waldner, podkreśliła znaczenie ukraińskiego systemu tranzytowego dla Europy i określiła państwo mianem ważnego partnera strategicznego. „Nie należy zapominać, że przez Ukrainę przepływa 80 proc. zasobów gazu ziemnego, z czego 20 proc. przypada na kraje Unii. Obecny kryzys pokazał, że Ukraina nie może zostać sama. Tutaj chodzi nie tylko o bezpieczeństwo energetyczne, ale też coraz silniejsze powiązania gospodarek" - powiedziała komisarz. Wspólne założenia planuje się wypełnić dzięki udzieleniu wsparcia dla reformy sektora energetycznego Ukrainy ${ }^{13}$.

Techniczna i finansowa pomoc z UE jest istotnym poparciem dla Ukrainy w procesie jej europejskich aspiracji. Członkowie UE podtrzymują wybór Ukrainy, sprzyjają jej rozwojowi i realizacji planów strategicznych i proponują rozwiązania istotnych problemów.

Ukraina jako uczestnik Polityki Sąsiedztwa Unii Europejskiej korzysta z preferencji, wynikających z europejskiej ENPI. Dzięki temu instrumentowi finansowemu współpraca Ukrainy z UE weszła na wyższy poziom: z pomocy czysto technicznej do specjalnych programów wsparcia reform i procesu integracji europejskiej.

Ukraina stała się pierwszym z poradzieckich państw, w którym wprowadzały się projekty Twinning. We wrześniu 2009 r. program miał już 37 projektów $^{14}$. Jeden z największych projektów - rekonstrukcja przejścia granicznego Rawa-Ruska-Hrebenne ${ }^{15}$. Budżet projektu wyniósł ponad $10 \mathrm{mln}$ euro. Przed rekonstrukcją zdolność przepustowa przejścia była około 4000 pasażerów, 1400 samochodów i 120 ciężarówek dziennie. Obecnie sięga 10000 osób, 3500 samochodów, 250 ciężarówek i 100 autobusów. Modernizowane przejście ma oddzielne linie kontroli celnej ciężarówek (wcześniej przegląd ładunku robiono bezpośrednio na drogach), nowe wygodne pomieszczenia, nowoczesne technologie informacyjne dla ochrony granicy.

13 Treść dokumentu dostępna: http://europa.eu/rapid/pressReleasesAction.do?reference $=$ SPEECH/ 09/137\&format $=$ HTML\&aged $=0$ \&language $=E N \&$ guiLanguage $=$ en .

14 Twinning projects - Forecast, treść dokumentu dostępna: http://twinning.com.ua/ index.php?option=com_content\&task=view\&id=378\&Itemid=156\&lang=english.

15 Європейський Союз - найбільний донор Украӥни: технічна і фінансова допомога з боку Свропейського Союзу та краӥн ЄC, treść dokumentu dostępna: http://www.delukr.ec.europa.eu/files/pages/4493/3.pdf. 
Ukraina to jedno z 8 państw na świecie posiadających znaczącą wiedzę i doświadczenie w programach kosmicznych oraz spore osiągnięcia w dziedzinie nawigacji satelitarnej (zastosowania GNSS, sprzęt, segment użytkownika, technologie regionalne). Ukraina i UE współpracują w dziedzinie europejskiego programu nawigacji satelitarnej Galileo. Porozumienie UE-Ukraina ustanawia możliwości współpracy w wielu sektorach nawigacji satelitarnej, a zwłaszcza w nauce i technologii, przemyśle, rozwoju rynku i usług oraz standaryzacji, częstotliwościach i certyfikacji. Przewiduje także rozszerzenie zasięgu EGNOS (European Geostationary Navigation Overlay Service) na Ukrainę i jej uczestnictwo w strukturach zarządzania systemem Galileo. Położenie geograficzne Ukrainy szczególnie predestynuje ją do udziału w usługach EGNOS ${ }^{16}$.

Obroty handlu między Ukrainą a Unią Europejską systematycznie rosną w ciągu ostatnich lat. W $2008 \mathrm{r}$. osiaggnęły 35,9\% mln euro. Udział UE-27 w całym eksporcie Ukrainy stanowi 27,1\%, w imporcie - 33,7\% (w 2008 r.). Głównym partnerem handlowym Ukrainy pozostaje Rosja (23,5\% udziału w ukraińskim eksporcie i $22,7 \%$ w imporcie). Kolejne w rankingu największych partnerów handlowych Ukrainy wśród krajów EU-27 w 2008 r. zajęły Niemcy (odpowiednio 2,7\% i 8,4\%), Polska (3,5\% udziału w ukraińskim eksporcie i 5\% w imporcie), Włochy (4,3\% eksportu i 2,8\% importu). Do UE Ukraina eksportuje metale, surowce energetyczne, artykuły rolno-spożywcze, wyroby przemysłu chemicznego. W imporcie dominują maszyny i urządzenia, artykuły chemiczne i przemysłowe ${ }^{17}$.

W 2008 r. inwestorzy zagraniczni ulokowali na Ukrainie $10911,1 \mathrm{mln}$ USD, z czego z krajów Unii Europejskiej pochodziło 8766,4 mln USD (80,3\%), a z państw WNP - 932,9 mln USD (8,6\%). Największe pozycje UE-27 zajęli inwestorzy z Włoch - 763,9 mln USD (których wcześniejsze, skumulowane inwestycje sięgały zaledwie poziomu około $250 \mathrm{mln}$ USD), Holandii - $672 \mathrm{mln}$ USD, Niemiec - 475,5 mln USD, Austrii - 378,2 mln USD, Wielkiej Brytanii (2273,5 mln USD) ${ }^{18}$.

Stanem na 1 stycznia 2009 r. na Ukrainę napłynęło 35,7 mln USD Bezpośrednich Inwestycji Zagranicznych. Największymi inwestorami były Niemcy (17,9\% udziału), Niderlandy (8,9\%), Austria (6,8\%), Wielka Bry-

16 Szerzej na stronie: http://www.twinning-space.org.ua/w/.

17 Handel zagraniczny Ukrainy w 2008 r., http://www.kijow.polemb.net/files/Tekstowe\%20pliki/I\%20polowa\%202009/notatka\%20HZ\%202008.pdf.

18 Bezpośrednie inwestycje zagraniczne na Ukrainie w 2008 r., http://www.kijow. polemb.net/files/Tekstowe\%20pliki/I\%20polowa\%202009/notatka\%20BIZ\%202008.pdf. 
tania $(6,4 \%)$, Szwecja $(3,5 \%)$, Francja $(3,4 \%)$ etc. Zdecydowana większość BIZ trafiła do sektorów nieprodukcyjnych, głównie sektora finansowego, związanego z rynkiem nieruchomości, handlem i usługami. Kraje Unii Europejskiej są największymi inwestorami na Ukrainie.

Ukraina pod względem znaczenia jest drugim po Rosji partnerem UE wśród nowych państw niepodległych. Sytuacja taka wynika z potencjału geograficznego, gospodarczego, militarnego Ukrainy oraz jej strategicznego położenia między UE a Rosją. Sąsiaduje bezpośrednio z czterema krajami Unii (Polską, Słowacją, Węgrami i Rumunią). Jest głównym państwem tranzytowym, jeśli chodzi o rosyjskie surowce energetyczne eksportowane do UE. Systematycznie rozwija się współpraca handlowo-gospodarcza. Unia Europejska i kraje UE są największymi donatorami Ukrainy.

Pogłębienie stosunków pomiędzy UE a Ukrainą przynosi obopólne polityczne i gospodarcze korzyści. Ukraina stała się członkiem Międzynarodowego Funduszu Pieniężnego, Europejskiego Banku Rekonstrukcji i Rozwoju, Rady Bezpieczeństwa i Współpracy w Europie, Światowej Organizacji Handlu.

Od kilku lat rządy Ukrainy deklarują, że jednym z głównych celów polityki zagranicznej tego państwa jest uzyskanie członkostwa w UE. Obecny i przyszły poziom społecznego i ekonomicznego rozwoju Ukrainy i ustalone procedury UE sprawiają, że w tym momencie przystąpienie Ukrainy do Unii Europejskiej jest niemożliwe. Ocena wstąpienia Ukrainy do UE jest niejednoznaczna. Jedną z przyczyn jest Rosja, która uważa cały obszar WNP (w tym i Ukrainę) za naturalny obszar swoich wyłącznych wpływów, i której istnienie jest zasadniczym elementem potwierdzenia tożsamości imperialnej. Wielkie inicjatywy polityczne UE są w tym świetle oceniane jako ingerencja w strefę wpływów Rosji. UE musi w tych warunkach działać bardzo ostrożnie, aby niepotrzebnie nie prowokować Moskwy, która jest cennym partnerem.

Zdaniem europejskich polityków, Unia Europejska w ostatnich czasach rozszerzyła się dość mocno, powinna raczej zająć się swoimi problemami wewnętrznymi niż planować dalsze rozszerzenie. Unia nie jest w stanie przyjąć tak dużego państwa, jak Ukraina. Ukraina będzie potrzebować olbrzymich nakładów. Musi się jeszcze wiele wydarzyć, aby UE spojrzała przychylniej na ten kraj.

Nadzieja Ukrainy na członkostwo w UE lub przybliżenie się do tego celu nie spełniła się. Jednakże pod względem partnerstwa zostały osiągnięte stabilne stosunki, zwłaszcza w porównaniu z innymi republikami poradzieckimi. 


\section{Summary}

Since the Soviet Union collapsed and Ukraine regained her independence, Ukraine has become an object of interest of the EU's foreign policy. Ukraine has immense economic and social potential, and a significant geopolitical location, particularly from the point of view of EU - Russian relations. Good mutual relations were corroborated by the Partnership and Cooperation Agreement between Ukraine and the EU. Signed on June 14, 1994, the Agreement provided for the reinforcement of mutual bonds as well as political and economic cooperation. Over its near twenty years of independence, Ukraine has taken part in several EU initiatives. A current issue at the Ukraine - EU summit, held in Kiev in December 2009, concerned the agreement of association to be drawn up that should replace the present Partnership and Cooperation Agreement between Ukraine and the EU. On account of a number of issues that the EU continues to have reservations about (the insufficient battle against corruption in Ukraine, the slow pace of economic reforms, and the lack of a uniform standpoint of the Ukrainian President, government and parliament) the signing of this Agreement has been postponed until next year. 